\title{
ОСОБЕННОСТИ РАЗМЕЩЕНИЯ САНИТАРНО-ЗАЩИТНЫХ ЗОН
}

\author{
Алина Евгеньевна Шуклина \\ Сибирский государственный университет геосистем и технологий, 630108, Россия, г. Новоси- \\ бирск, ул. Плахотного, 10, магистрант кафедры кадастра и территориального планирования, \\ тел. (961)848-00-11, e-mail: shuklinaa@list.ru
}

\section{Ирина Ивановна Бочкарева}

Сибирский государственный университет геосистем и технологий, 630108, Россия, г. Новосибирск, ул. Плахотного, 10, кандидат биологических наук, зав. кафедрой экологии и природопользования, тел. (383)361-06-86, e-mail: family_i@mail.ru

В статье продемонстрированы особенности размещения санитарно-защитных зон. Наличие санитарно-защитной зоны у объекта негативного воздействия является одним из мероприятий по уменьшению его негативного воздействия на окружающую среду. Описана значимость наличия санитарно-защитной зоны у объекта негативного воздействия, классификация размерности зон, срок размещения, ограничения использования территории зоны. Приведен перечень объектов, наличие которых на территории санитарно-защитной зоны разрешено и запрещено размещать. Рассмотрена проблема отсутствия у объектов негативного воздействия санитарно-защитных зон, а также наличие у границ этих объектов зон жилой застройки. В качестве решения данной проблемы предложено установление санитарно-защитных зон в сокращенном виде. Описано каким образом и при каких условиях возможно сократить территорию санитарно-защитной зоны и когда она считается официально установленной.

Ключевые слова: санитарно-защитная зона, жилая зона, Единый государственный реестр недвижимости, объект негативного воздействия, сокращение границ территории, деятельность объекта негативного воздействия, режим использования санитарно-защитной зоны

\section{FEATURES OF LOCATION OF SANITARY PROTECTION ZONES}

\section{Alina E. Shuklina}

Siberian State University of Geosystems and Technologies, 10, Plakhotnogo St., Novosibirsk, 630108, Russia, Student, phone: (961)848-00-11, e-mail: shuklinaa@list.ru

\section{Irina I. Bochkareva}

Siberian State University of Geosystems and Technologies, 10, Plakhotnogo Str., Novosibirsk, 630108, Russia, Ph. D., Associate Professor, Head of the Department of Ecology and Environmental Management, phone: (383)361-08-86, e-mail: family_i@mail.ru

The article demonstrates the features of the placement of sanitary protection zones. The presence of a sanitary protection zone near the object of negative impact is one of the measures to reduce the negative impact on the environment from it. The significance of the presence of a sanitary protection zone near the object of negative impact, classification of the dimensions of the zones, period of placement, restrictions on the use of the territory of the zone are described. There is a list of objects, the presence of which in the territory of the sanitary protection zone is allowed and prohibited to be placed. The problem of the absence of the negative impact of sanitary protection zones the objects, as well as the presence of residential development zones at the boundaries of these objects is considered. As a solution to this problem, it is proposed to establish sanitary protection zones in an 
abbreviated form. It describes how and under what conditions it is possible to reduce the territory of the sanitary protection zone and when it is considered officially established.

Keywords: sanitary protection zone, residential zone, Unified State Register of Real Estate, object of negative impact, reduction of the boundaries of the territory, activities of the object of negative impact, regime of use of the sanitary protection zone

На сегодняшний день одним из обязательных направлений в деятельности предприятий является применение мер по уменьшению негативного воздействия на окружающую среду. От того в какой сфере деятельности занято предприятие и какие размеры оно имеет будут зависеть виды и объемы работ по охране окружающей среды. В Ф3 №52 и ряде других нормативно-правовых актах прописано, что каждый гражданин Российской Федерации имеет право на экологически благополучную и чистую окружающую среду. Одной из мер, направленных на сокращения негативного воздействия от предприятия, является наличие у него санитарно-защитной зоны (С33) [1-4].

С33 представляет собой территорию вокруг объекта негативного воздействия (OHВ), где установлен определенный режим и размер которой обеспечивает сокращение химического, физического и биологического загрязнения на атмосферу до значений, которые установлены гигиеническими нормативами. Своего рода С33 представляет собой буферную зону между производственной территорией и жилой зоной. Размеры санитарно-защитных зон, в первую очередь, зависят от деятельности объекта негативного воздействия и имеют свою определенную классификацию, которая прописана в СанПиН 2.2.1/2.1.1.1200-03. Всего по санитарной классификации выделяют пять классов размерности С33 для предприятий: первый класс - 1000 м, второй класс - 500 м, третий класс - 300 м, четвертый класс - 100 м, пятый класс - 50 м. Установление границы С33 объекта негативного воздействия происходит один раз на бессрочное время в том случае, если на предприятии не проводятся значительные изменения технологического процесса, которые могут повлиять на уровень воздействия на окружающую среду [5-7].

Эксплуатация территории С33 осуществляется с учетом ограничений, которые установлены градостроительными нормативно-правовыми актами, а также санитарными нормами и правилами. На территории С33 градостроительная деятельность проводится с установленными ограничениями к которым относится запрет на размещение жилой застройки, зон расположения дачных, садово-огородных, коттеджных участков, рекреационных зон (санатории, дома отдыха, территории курортов), зон общественно-делового значения (образовательные учреждения, объекты здравоохранения, спортивные сооружения), а также объекты фармацевтического производства, объекты пищевой промышленности, водопроводные сооружения для подготовки и хранения питьевой воды на продукцию и сырье которых может повлиять негативное воздействие от предприятия [5, 8-10].

В пределах границы санитарно-защитной зоны объекта негативного воздействия разрешено размещать нежилые помещения (административные здания, объекты торговли, гаражи и т.д.), транзитные и местные коммуникации (газои нефтепроводы, ЛЭП, канализационные станции и т.д.), АЗС, СТО. 
Территория С33 или ее часть не может считаться дополнительной площадью территории ОНВ и использоваться для его увеличения промышленной территории без обоснования корректирования границ СЗ3.

Наличие разработанной санитарно-защитной зоны для объекта негативного воздействия в пределах которой расположены жилые застройки и другие зоны жизнедеятельности людей является необходимым мероприятием для минимизации этого воздействия. При решении вопросов размещения предприятий и установления их санитарно-защитных зон необходимо соблюдение санитарных правил и норм, направленных на обеспечение благоприятной среды для жизнедеятельности населения [11-14].

Многие объекты негативного воздействия не имеют С33. Большая часть этих объектов находится в непосредственной близости к зонам жилой застройки и жизнедеятельности людей, что делает невозможным установление санитарнозащитной зоны в полном размере. Данная проблема возникла по причине того, что преобладающая часть городских территорий была построена в то время, когда значимости С33 не отдавалось большой роли и не было такого большого количества предприятий с разной степенью негативного воздействия на окружающую среду как есть на сегодняшний день. Помимо этого, не все объекты негативного воздействия имеют свободные площади вокруг территории предприятия на которой возможно разместить санитарно-защитную зону [15-17].

Для случаев, рассмотренных выше, установление СЗ3 возможно в сокращенном виде. Конечный размер будет достигаться за счет смещения границ территории санитарно-защитной зоны от зон жилой застройки и жизнедеятельности людей. Законом не предусмотрены определенные числовые значения, на которые разрешено сокращать С 33 , поэтому размер зоны определяется исходя расстоянию между территорией ОНВ и зон жизнедеятельности населения. Одним из условий такого сокращения будет являться непревышение предельно-допустимых концентраций (ПДК) на границе С33 в результате проведения замеров $[18,19]$.

Установление границ территории С33 и ограничения использования земельных участков, которые находятся в ее пределах считается с того момента, когда данные о них внесены в Единый государственный реестр недвижимости (ЕГРН).

Процедура установления С33 и использования земельных участков, которые находятся в границах территории С33, прописана в Постановлении Правительства № 222. В нем утверждены этапы подготовки и принятия решений об установлении, изменении, прекращении существования санитарно-защитных зон [20].

\section{БИБЛИОГРАФИЧЕСКИЙ СПИСОК}

1. О санитарно-эпидемиологическом благополучии населения [Электронный ресурс]: федер. закон от 30.03.1999 № 52. - Доступ из справ. -правовой системы «КонсультантПлюс».

2. Конституция Российской Федерации [Электронный ресурс]: Конституция Российской Федерации от 12.12.1993. - Доступ из справ. -правовой системы «КонсультантПлюс». 
3. Об охране окружающей среды [Электронный ресурс]: федер. закон от 10.01.2002 № 7.Доступ из справ. -правовой системы «КонсультантПлюс».

4. Об охране атмосферного воздуха [Электронный ресурс]: федер. закон от 04.05.1999 N 96-Ф3 - Доступ из справ. -правовой системы «КонсультантПлюс».

5. О введении в действие новой редакции санитарно-эпидемиологических правил и нормативов СанПиН 2.2.1/2.1.1.1200-03 "Санитарно-защитные зоны и санитарная классификация предприятий, сооружений и иных объектов" [Электронный ресурс]: постановление Главного государственного санитарного врача Российской Федерации от 25.09.2007 № 74. - Доступ из справ. -правовой системы «КонсультантПлюс».

6. Максимов В.А., Клишина М. Кого и как защищает санитарно-защитная зона // Землеустройство, кадастр и мониторинг земель - 2017. - №6 (149). - С. 11 - 17.

7. Сайманова О.Г., Поршина Е.Г. Проблемы расчета санитарно-защитной зоны предприятий // 77-ая всероссийская научно-техническая конференция «Традиции и инновации в строительстве и архитектуре»: сб. статей (Самара, 26 - 30 октября 2020). - Самара: СГТУ, 2020. C. $530-535$.

8. Градостроительный кодекс Российской Федерации [Электронный ресурс]: федер. закон от 29.12.2004 № 190. - Доступ из справ. -правовой системы «КонсультантПлюс».

9. Тугушева Я.В. Анализ правового регулирования санитарно-защитных зон (C33) // XIV региональная научно-практическая конференция «Развитие города глазами студентов»: сб. материалов (Москва, 25 апреля 2019). - Москва: МИЭТ, 2019. С. 13-17.

10. Лощинина А.М., Шемякина Я.С., Кривко В.В. Санитарно-защитная зона как элемент обеспечения экологической безопасности и безопасности жизнедеятельности человека // Международная научно-практическая конференция «Современное научное знание: теория, методология, практика»: сб. материалов (Смоленск, 31 января 2017). - Смоленск: ООО «НОВАЛЕНСО», 2017. С. $9-12$.

11. Шильникова Н. В., Андрияшина Т.В. К вопросу о санитарно-защитных зонах производственных объектов // Научный альманах - 2019. - № 4-2 (54) - С. 79-82.

12. Смоляков Я.С., Уфимцева М.Г. Обоснование санитарно-защитной зоны предприятия вблизи жилой зоны // Мир инноваций - 2020. - №1. - С. 27 - 30.

13. Московкина И.С., Васильева Т.А. Современные проблемы при проектировании санитарно-защитных зон // Сборник научных трудов по материалам III международной научной конференции (Санкт-Петербург, 28 мая 2017). - Санкт-Петербург: Общественная наука, 2017. C. $9-12$.

14. Понаморев М.В. Санитарно-защитные зоны промышленных объектов как инструмент охраны земель и городских территорий // Международная научная конференция «Экологическая политика: векторы сбалансированного развития. Правовое обеспечение комплексного развития территорий»: сб. материалов (Москва, 14 декабря 2017 - 15 марта 2018). Москва: МГУГК, 2018. С. $272-273$.

15. Киприянова Е.Н., Смирнова В.О. Санитарно-защитная зона промышленного предприятия как элемент урбанизированных территорий // Моделирование и ситуационное управление качеством сложных систем: сб. материалов (Санкт-Петербург, 10 - 14 апреля 2017). Санкт-Петербург: СПбГУАП, 2017. С. 155 - 159.

16. Путерман Л.Н., Богданова Е.Ю. Санитарно-защитные зоны в планировочной структуре городов - нормативы и реальность // Вестник. Зодчий. 21 век. - 2008. - №3 (28). C. $18-23$.

17. Михайлова Т.В., Московкина И.С. Современные проблемы при проектировании санитарно-защитных зон // Жилищное хозяйство и коммунальная инфраструктура - 2017. - №1 (1). - C. $26-30$. 
18. Мунтяну П.В. О некоторых вопросах сокращения размера санитарно-защитных зон промышленных предприятий в Российской Федерации// Вестник Удмуртского университета 2019. -T. 29, № 2 - C. 201-206.

19. Рахманина Ю. А., Основы оценки риска для здоровья населения при воздействии химических веществ, загрязняющих окружающую среду [Текст] / Ю.А. Рахманина // НИИ ЭЧ и ГОС. - М., 2012. -408 с.

20. Об утверждении Правил установления санитарно-защитных зон и использования земельных участков, расположенных в границах санитарно-защитных зон [Электронный ресурс]: постановление Правительства Российской Федерации от 03.03.2018 № 222. - Доступ из справ. - правовой системы «КонсультантПлюс».

(C) А. Е. Шуклина, И. И. Бочкарева, 2021 